\title{
Chromothripsis Identified by Copy Number Profiling in a Case of Plasma Cell Leukaemia
}

\author{
Min Ji Sohn ${ }^{1}$, Yeung \\ Chul Mun ${ }^{2}$, Chu \\ Myong Seong ${ }^{2}$, Wha \\ Soon Chung ${ }^{1}$, and \\ Jungwon Huh ${ }^{1}$ \\ Departments of ${ }^{1}$ Laboratory \\ Medicine and ${ }^{2}$ Internal \\ Medicine, Ewha Womans \\ University School of \\ Medicine, Seoul, Korea
}

\author{
Corresponding author: \\ Jungwon Huh \\ Department of Laboratory \\ Medicine, Ewha Womans \\ University School of Medicine, \\ 1071 Anyangcheon-ro, \\ Yangcheon-gu, Seoul 158-710, \\ Korea \\ Tel: +82-2-2650-5287 \\ Fax: +82-2-2650-5091 \\ E-mail: JungWonH@ewha.ac.kr
}

\begin{abstract}
A genomic instability called chromothripsis occurs as a single catastrophic event, generating massive complex genomic rearrangement with a possible characteristic pattern of copy number oscillations. Here, we report a case of secondary plasma cell leukaemia (PCL) showing chromothripsis identified by single nucleotide polymorphism array (SNP-A)based karyotyping. A 53-year-old male patient was diagnosed as having secondary PCL four years after he was diagnosed with multiple myeloma, and he died four days later due to intracerebral haemorrhage. Chromosomal analysis and fluorescence in situ hybridization (FISH) revealed the deletions of $13 \mathrm{q}$ and $17 \mathrm{p}$ and an insertion of 1q. Further, genomic aberrations that were not detected by chromosomal analysis and FISH were identified by SNP-A. In particular, SNP-A revealed numerous alternating copy number state switches involving one, two, or three copy number states on chromosome $7 \mathrm{q}$, suggesting the presence of chromothripsis. The present case suggests that chromothripsis may occur in secondary PCL and can be inferred from genomic copy number profiles identified by SNP-A.
\end{abstract}

(J Lab Med Qual Assur 2014;36:107-112)

Key Words : Chromothripsis, Plasma cell leukaemia, Copy number, Array

Received March 25, 2014, Revision received May 9, 2014, Accepted May 9, 2014

\section{INTRODUCTION}

Plasma cell leukemia (PCL) is a rare and aggressive variant of plasma cell dyscrasias [1-3]. Secondary PCL arises in patients with a history of multiple myeloma (MM) who have progressed to a leukemic phase, while primary PCL occurs in individuals without a preceding diagnosis of MM [1-3]. Few comprehensive molecular studies on PCL exist due to the low frequency of this entity and the mechanisms contributing to the pathogenesis of PCL are not fully understood.

The model of genomic instability and evolution (gradual acquisition of genomic rearrangements and somatic mutations over time) is a generally accepted concept for cancer biogenesis. On the other hand, a new mechanism of genomic instability called chromothripsis ('chromo' from chromosome; 'thripsis' for shattering into pieces) has recently been described [4-9]. Chromothripsis is postulated to occur in a single catastrophic event in which a genome is shattered into tens to hundreds of fragments and then stitched them back together, generating a massive complex genomic rearrangement [4-9]. Chromothripsis is found in $2 \%$ to $3 \%$ of cancer, especially in aggressive forms of cancer [4-9]. Chromosomes affected by chromothripsis show a characteristic pattern of copy number oscillations [4-10]. Therefore, evidence for chromothripsis can be inferred from array based karyotyping which allows genomic copy number profiles [4- 


\section{Journal of LABORATORY MEDICINE and QUALITY ASSURANCE \\ Min Ji Sohn et al • Chromothripsis in Plasma Cell Leukaemia}

10]. Here, we report a case of secondary PCL showing the hallmarks of chromothripsis on chromosome 7 identified by copy number profiling using array based karyotyping.

\section{CASE REPORT}

A 53-year old male was diagnosed with MM (IgA lambda type, stage 1 according to International Staging System) in March 2005. He received chemotherapy with vincristine, doxorubicin, and dexamethasone (VAD) as frontline treatment. After six cycle of VAD, chemotherapy was changed to hyperfractionated cyclophosphamide, vincristine, doxorubicin, and dexamethasone (hyperCVAD) because of inadequate response to VAD. In April 2006, he received autologous peripheral blood stem cell transplantation, but secondary PCL developed four years later after the diagnosis of MM (March 2009). He started chemotherapy with hyperCVAD, but expired four days after the diagnosis of secondary PCL due to intracerebral hemorrhage.

Cytogenetic studies were performed on unstimulated 24- and 48-hour cultures, using fresh bone marrow aspirates obtained at diagnosis and analyzed according to the International System for Human Cytogenetic Nomenclature [11]. Fluorescence in situ hybridization (FISH) was performed using commercially available probes (Abbott/Vysis, Downers Grove, IL, USA, and Kreatech, Amsterdam, The Netherlands). The genome-

Table 1. Genomic aberrations identified by single nucleotide polymorphism array-based karyotyping in a patient with secondary plasma cell leukaemia

\begin{tabular}{|c|c|c|c|c|c|}
\hline Aberrations & $\begin{array}{l}\text { Chromosome } \\
\text { start }\end{array}$ & $\begin{array}{c}\text { Chromosome } \\
\text { end }\end{array}$ & Nucleotide start & Nucleotide end & Size $(\mathrm{Mb})$ \\
\hline Chromothripsis & $7 \mathrm{q} 21.11$ & $7 q 36$ & - & - & \\
\hline Gain* & $1 \mathrm{q} 21.1^{*}$ & $1 \mathrm{q} 32.2$ & $144,007,036$ & $210,348,212$ & 66 \\
\hline Copy neutral loss of heterozygosity & $1 \mathrm{q} 32.2$ & $1 \mathrm{q} 44.0$ & $210,348,212$ & $246,993,683$ & 37 \\
\hline Loss & $2 \mathrm{q} 36.3$ & $2 \mathrm{q} 37.1$ & $230,071,367$ & $231,486,020$ & 1 \\
\hline Loss & $5 \mathrm{p} 15.31$ & $5 p 15.31$ & $6,667,426$ & $8,811,026$ & 2 \\
\hline Loss & $6 \mathrm{p} 21.31$ & $6 \mathrm{p} 12.1$ & $34,571,644$ & $55,489,073$ & 21 \\
\hline Loss & $6 \mathrm{q} 16.3$ & $6 \mathrm{q} 27.0$ & $103,608,027$ & $170,521,052$ & 67 \\
\hline Loss & $8 \mathrm{p} 21.2$ & $8 \mathrm{p} 21.2$ & $23,795,316$ & $25,675,709$ & 2 \\
\hline Gain & $9 \mathrm{p} 24.3$ & $9 \mathrm{q} 22.2$ & 0 & $91,860,911$ & 92 \\
\hline Gain & $9 q 31.3$ & $9 \mathrm{q} 34.3$ & $114,110,176$ & $141,091,382$ & 27 \\
\hline Loss & $11 \mathrm{q} 22.3$ & $11 \mathrm{q} 22.3$ & $103,533,398$ & $104,419,659$ & 0.9 \\
\hline Loss & $11 \mathrm{q} 24.1$ & $11 \mathrm{q} 24.2$ & $121,921,479$ & $126,296,678$ & 4 \\
\hline Loss & $12 \mathrm{p} 13.2$ & $12 \mathrm{p} 13.1$ & $11,803,607$ & $13,192,749$ & 1 \\
\hline $\operatorname{Loss}^{*}$ & Whole $13 \mathrm{q}^{\star}$ & - & - & - & \\
\hline Loss & $14 \mathrm{q} 22.2$ & $14 \mathrm{q} 31.3$ & $54,715,844$ & $86,461,243$ & 32 \\
\hline Loss & $16 q 12.1$ & $16 q 12.1$ & $46,534,976$ & $52,070,341$ & 6 \\
\hline Loss & $16 \mathrm{q} 21$ & $16 q 22.1$ & $63,781,052$ & $67,663,176$ & 4 \\
\hline Loss $^{*}$ & $17 \mathrm{p} 13.1^{*}$ & $17 \mathrm{p} 12.0$ & $7,303,224$ & $13,035,617$ & 6 \\
\hline Gain & $19 \mathrm{p} 13.11$ & $19 \mathrm{p} 11.0$ & $19,119,490$ & $24,451,217$ & 5 \\
\hline Loss & $20 \mathrm{p} 13$ & $20 \mathrm{p} 13.0$ & $3,447,223$ & $4,020,933$ & 0.6 \\
\hline Loss & $22 \mathrm{q} 11.21$ & $22 \mathrm{q} 12.2$ & $21,840,421$ & $29,831,619$ & 8 \\
\hline Loss & $22 \mathrm{q} 13.1$ & $22 \mathrm{q} 13.32$ & $38,319,525$ & $49,380,863$ & 11 \\
\hline Gain & $\mathrm{Xq} 23$ & $\mathrm{Xq} 28$ & $113,885,278$ & $154,929,486$ & 41 \\
\hline
\end{tabular}

"Genomic aberrations confirmed by fluorescence in situ hybridization. 


\section{Journal of LABORATORY MEDICINE and QUALITY ASSURANCE \\ Min Ji Sohn et al • Chromothripsis in Plasma Cell Leukaemia}

wide human SNP ver. 6.0 arrays (Affymetrix, Santa Clara, CA, USA) were used for single nucleotide polymorphism array (SNP-A) according to the manufacturer's instructions (Plasma cells constituted 86\% of bone marrow nucleated cells at the time of diagnosis of secondary PCL). Data were analyzed according to the algorithm adopted in the previous report [12] using Chromosome Suite Analysis software (Affymetrix).

This patient showed normal karyotype at the diagnosis of MM: 46,XY[20]. However, at the time of secondary PCL, chromosomal analysis revealed that deletions of $13 q$ and $17 p$ was in one metaphase among 20 metaphases analyzed: 46,XY,del(13) (q12q14),del(17) (p13) [1]/46,XY[19]. Interphase FISH showed deletions of $13 q(62 \%)$ and $17 p(59 \%)$ and gains of $1 q(49 \%)$, but $\operatorname{IgH}$ rearrangements including $\mathrm{t}(11 ; 14), \mathrm{t}(4 ; 14)$, and $\mathrm{t}(14 ; 16)$ abnormalities (IgH/CCND1, IgH/FGFR3, and IgH/MAF, respectively) and 8p21 deletion were not observed. By SNP-A, genomic aberrations were identified (gains of chromosome 1q, 9, 19p, Xq; losses of chromosome 2q, 5p, 6, 8p, 11q, 12p, 13q, 14q, 16q, 17p, 20p, 22q; сорy neutral LOH of chromosome 1q). A detailed description of the genomic aberrations identified by SNP-A is shown in Table 1. In particular, SNP-A revealed numerous alternating copy number state switches involving one, two or three copy number states that were localized to chromosome 7q, suggesting the presence of chromothripsis (Fig. 1).

\section{DISCUSSION}

The present case showed that a characteristic pattern of chromothripsis could be identified by copy number profiling using SNP-A based karyotyping in a patient with secondary PCL. In addition, genomic aberrations not detected by chromosomal analysis and FISH could be detected by SNP-A.

Chromothripsis is reported in $2 \%$ to $3 \%$ of cancers,

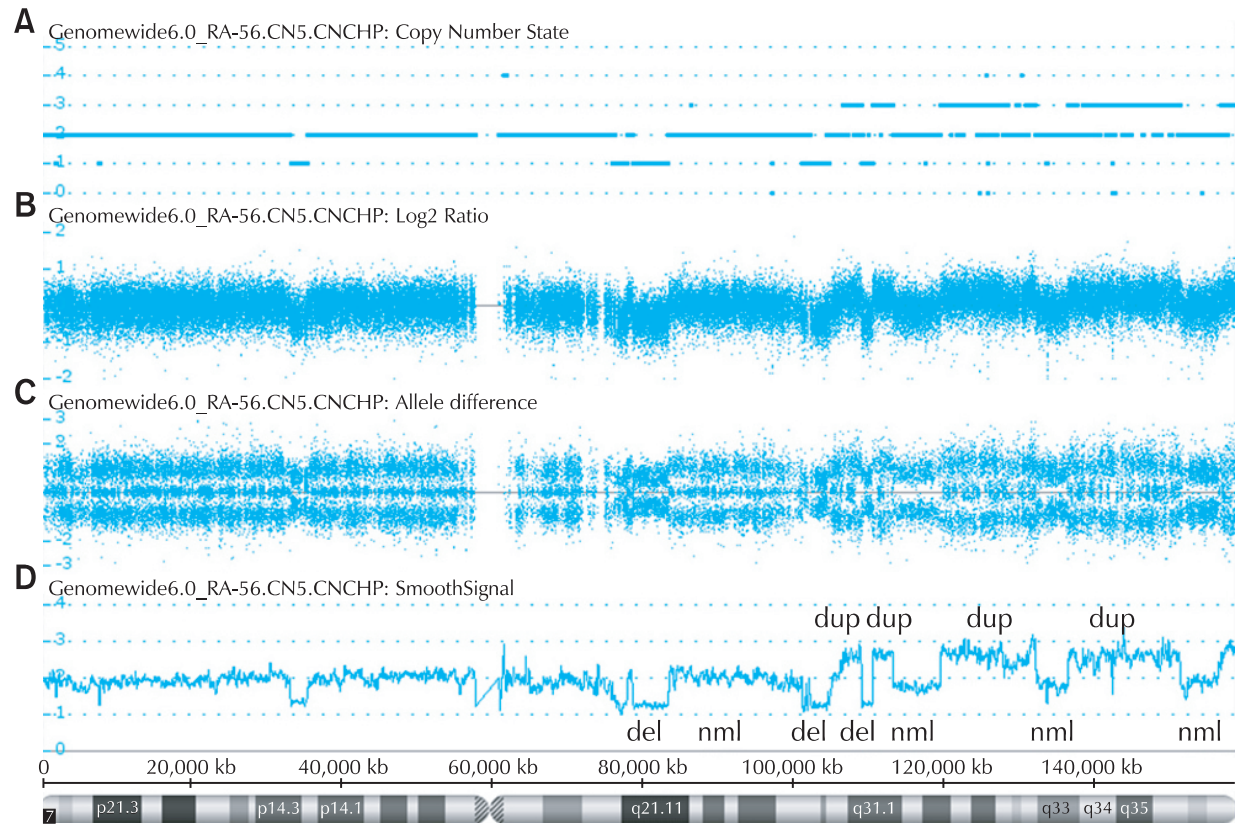

Fig. 1. Chromothripsis patterns on chromosome $7 \mathrm{q}$ inferred by single nucleotide polymorphism (SNP)-array showing copy number $(\mathrm{CN})$ oscillations. Numerous alternating $\mathrm{CN}$ state switches involving a deletion (del), a normal copy (nml) sequence, or a duplication (dup) were identified. (A) $\mathrm{CN}$ status $(\mathrm{CN}=1$, copy number $1 ; \mathrm{CN}=2$, copy number 2 ; $\mathrm{CN}=3$, copy number 3). (B) Log2 ratio represents the ratio of test and reference signals. (C) The allele difference represents genotyping calls or the frequency of the alleles (homozygous SNPs cluster at ratios -1 and 1 and heterozygous SNPs 0). (D) The smooth signal value is calculated using the intensity values of the flanking probes. 


\title{
Journal of LABORATORY MEDICINE and QUALITY ASSURANCE
}

\author{
Min Ji Sohn et al • Chromothripsis in Plasma Cell Leukaemia
}

spanning a wide variety of tumor types; osteosarcoma (33\%), bone cancer $(25 \%)$, chordoma (18\%), neuroblastoma (11\%), medulloblastoma (13\%), and so on $[4,6]$. In addition, chromothripsis has also been reported in hematologic malignancies; chronic lymphocytic leukemia (10\%), 1.3\% of newly diagnosed MM [10] and 8\% of AML [8]. In particular, 47\% of AMLs with a somatically acquired TP53 mutant genotype displayed chromothripsis, whereas only $1 \%$ of AMLs with wild-type TP53 showed chromothripsis, suggesting a close link between somatic TP53 mutations and chromothripsis [8]. Chromothripsis may lead to the generation of amplifications of one or more oncogene or deletion of one or more tumor suppressor genes at a single catastrophic event. As for prognosis, 50\% of MM patients with chromothripsis experienced rapid relapse within 10 months after diagnosis and $40 \%$ of them died (overall survival 6 to 34 months) [10]. In particular, a 34-year-old patient died 6 months after the diagnosis of PCL) [10]. Our case died 4 days after the diagnosis of secondary PCL. Taken together, chromothripsis may be associated with poor outcome in cancers. A further study is needed in a large cohort of PCL including sequential samples from MM to PCL. In one study, chromothripsis patterns found in MM were different among the patients and showed that chromosomes $1 \mathrm{q}$ and $16 \mathrm{q}$ were frequently involved [10], while our case showed chromothripsis on chromosome 7q.

To identify chromothripsis, a powerful methodology of massively parallel paired-end sequencing should be used for its ability to detect complex series of balanced inter- and intra-chromosomal rearrangements caused by chromothripsis $[4,8,9]$. However, it has not yet been routinely used for clinical diagnosis. Analysis of high resolution copy number profiles using SNP-A can identify copy number oscillations suggestive of chromothripsis $[4,7,10]$.

In this study, SNP-A revealed genomic aberrations (such as 1q, 6q, 8p, 13q, 14q, 16q, and 17p), similar to those found in MM or PCL reported by other studies [1315]. One study using SNP-A showed that patients with primary PCL had genetic aberrations with a median 20 per sample (range, 6 to 82) [15]. According to one report, a patient with secondary PCL had highly complex karyotype which could be characterized by various FISH techniques and was not able to resolve genetic changes only by conventional chromosomal analysis [16]. In our case, 23 genomic aberrations including chromothripsis were identified by SNP-A, although chromosomal analysis revealed only $13 \mathrm{q}$ and $17 \mathrm{p}$ abnormalities. Taken together, it is likely that PCL is associated with increasing genomic complexity. In addition, this study showed that SNP-A could be useful to detect cryptic genomic aberrations, not detected by chromosomal and FISH analyses, consistent with the previous studies [12-15,17].

In summary, our study suggests that chromothripsis may be associated with PCL, and SNP-A based karyotyping could be useful for identifying chromothripsis in the clinical field.

\section{ACKNOWLEDGEMENTS}

This study was supported by the Basic Science Research Program through the National Research Foundation of Korea funded by the Ministry of Education, Science, and Technology (NRF-2012R1A1A2044138).

\section{REFERENCES}

1. Jimenez-Zepeda VH, Dominguez-Martinez VJ. Plasma cell leukemia: a highly aggressive monoclonal gammopathy with a very poor prognosis. Int J Hematol 2009; 89:259-68.

2. Albarracin F, Fonseca R. Plasma cell leukemia. Blood Rev 2011;25:107-12.

3. Pagano L, Valentini CG, De Stefano V, Venditti A, Visani G, Petrucci MT, et al. Primary plasma cell leukemia: a retrospective multicenter study of 73 patients. Ann Oncol 2011;22:1628-35.

4. Stephens PJ, Greenman CD, Fu B, Yang F, Bignell GR, Mudie LJ, et al. Massive genomic rearrangement acquired in a single catastrophic event during cancer development. Cell 2011;144:27-40.

5. Maher CA, Wilson RK. Chromothripsis and human 


\section{Journal of LABORATORY MEDICINE and QUALITY ASSURANCE}

Min Ji Sohn et al • Chromothripsis in Plasma Cell Leukaemia

disease: piecing together the shattering process. Cell 2012;148:29-32.

6. Liu P, Erez A, Nagamani SC, Dhar SU, Kolodziejska KE, Dharmadhikari AV, et al. Chromosome catastrophes involve replication mechanisms generating complex genomic rearrangements. Cell 2011;146:889-903.

7. Korbel JO, Campbell PJ. Criteria for inference of chromothripsis in cancer genomes. Cell 2013;152:1226-36.

8. Rausch T, Jones DT, Zapatka M, Stutz AM, Zichner T, Weischenfeldt J, et al. Genome sequencing of pediatric medulloblastoma links catastrophic DNA rearrangements with TP53 mutations. Cell 2012;148:59-71.

9. Kloosterman WP, Hoogstraat M, Paling O, TavakoliYaraki M, Renkens I, Vermaat JS, et al. Chromothripsis is a common mechanism driving genomic rearrangements in primary and metastatic colorectal cancer. Genome Biol 2011;12:R103.

10. Magrangeas F, Avet-Loiseau H, Munshi NC, Minvielle S. Chromothripsis identifies a rare and aggressive entity among newly diagnosed multiple myeloma patients. Blood 2011;118:675-8.

11. Shaffer LG, Slovak ML, Campbell LJ; International Standing Committee on Human Cytogenetic Nomenclature. ISCN 2009: an international system for human cytogenetic nomenclature (2009). Basel: Karger, 2009.

12. Maciejewski JP, Tiu RV, O’Keefe C. Application of arraybased whole genome scanning technologies as a cytoge- netic tool in haematological malignancies. Br J Haematol 2009;146:479-88.

13. Kamada Y, Sakata-Yanagimoto M, Sanada M, SatoOtsubo A, Enami T, Suzukawa K, et al. Identification of unbalanced genome copy number abnormalities in patients with multiple myeloma by single-nucleotide polymorphism genotyping microarray analysis. Int J Hematol 2012;96:492-500.

14. Lopez-Corral L, Sarasquete ME, Bea S, Garcia-Sanz R, Mateos MV, Corchete LA, et al. SNP-based mapping arrays reveal high genomic complexity in monoclonal gammopathies, from MGUS to myeloma status. Leukemia 2012;26:2521-9.

15. Mosca L, Musto P, Todoerti K, Barbieri M, Agnelli L, Fabris S, et al. Genome-wide analysis of primary plasma cell leukemia identifies recurrent imbalances associated with changes in transcriptional profiles. Am J Hematol 2013;88:16-23.

16. Heller A, Fricke HJ, Starke H, Loncarevic IF, Claussen U, Liehr T. Characterization of a highly aberrant plasma cell leukemia karyotype: a case report. Oncol Rep 2004;11:8992.

17. Slovak ML, Smith DD, Bedell V, Hsu YH, O'Donnell M, Forman SJ, et al. Assessing karyotype precision by microarray-based comparative genomic hybridization in the myelodysplastic/myeloproliferative syndromes. Mol Cytogenet 2010;3:23. 
형질세포백혈병에서 유전자복제수 프로파일로 검색된 염색 체파열

\section{손민지 ${ }^{1} \cdot$ 문영철 $^{2} \bullet$ 성주명 ${ }^{2} \bullet$ 정화순 $^{1} \bullet$ 허정원 $^{1}$}

이화여자대학교 의학전문대학원 ${ }^{1}$ 진단검사의학교실, ${ }^{2}$ 내과학교실

게놈 불안정성의 새로운 기전인 염색체파열(chromothripsis)은 한 번의 치명적인 사건으로 대규모 의 복잡한 게놈 재배열을 생성하게 되며, 유전자복제수 진동의 특징적인 형태를 나타낼 수 있다. 저자 들은 이차성 형질세포백혈병 환자에서 어레이기반 핵형분석으로 관찰한 염색체파열 증례를 기술하고 자 한다. 4년 전 다발성골수종으로 진단받았던 53세 남자가 이차성 형질세포백혈병으로 진행하였고, 4일 후 뇌출혈로 사망하였다. G-분염법 염색체검사 및 형광제자리부합법검사에서 염색체 $13 q$ 결실, $17 p$ 결실과 $1 q$ 획득이 관찰되었으며, $\mathrm{t}(11 ; 14), \mathrm{t}(4 ; 14), \mathrm{t}(14 ; 16)$ 재배열은 관찰되지 않았다. 단일 염기다형성 어레이기반 핵형분석은 전체 게놈을 대상으로 SNP ver. 6.0 array (affymetrix, USA)로 시행하였고, G-분염법 염색체검사 및 형광제자리부합법검사에서 검색할 수 없었던 다양한 유전체 변 화 $1 \mathrm{q}, 9,19 \mathrm{p}, \mathrm{Xq}$ 의 획득; $2 \mathrm{q}, 5 \mathrm{p}, 6,8 \mathrm{p}, 11 \mathrm{q}, 12 \mathrm{p}, 13 \mathrm{q}, 14 \mathrm{q}, 16 \mathrm{q}, 17 \mathrm{p}, 20 \mathrm{p}, 22 \mathrm{q}$ 의 소실; $1 \mathrm{q}$ 의 copy neutral loss of heterozygosity)를 추가적으로 확인할 수 있었다. 특히 염색체 $7 q$ 부위에 유전자복제수가 교대로 1 개, 2 개 또는 3 개로 다양하게 변하는 염색체파열현상을 관찰할 수 있었다. 이번 연구를 통해서 염색체파열은 이차성 형질세포백혈병에서 발생할 수 있으며, 어레이기반 핵형분 석을 통하여 유전자복제수 진동패턴을 관찰함으로써 확인할 수 있었다.

(J Lab Med Qual Assur 2014;36:107-112) 